\title{
Triggering preservice teachers' writing skills through genre-based instructional model viewed from creativity
}

\author{
Haerazi Haerazi ${ }^{1}$, Lalu Ari Irawan ${ }^{2}$, Taufik Suadiyatno ${ }^{3}$, Heri Hidayatullah ${ }^{4}$ \\ 1,2Magister of English Education, Mandalika University of Education, Indonesia \\ ${ }^{3,4}$ Department of English Education, Mandalika University of Education, Indonesia
}

\section{Article Info \\ Article history: \\ Received Nov 21, 2019 \\ Revised Jan 27, 2020 \\ Accepted Feb 13, 2020}

\section{Keywords:}

Creativity

GBI model

PBI model

Writing skills

\begin{abstract}
This study was aimed at finding out the effectiveness of genre-based instructional model in the teaching of writing skills viewed from students' creativity. This study employed a quasi-experimental research design. The samples consisted of two classes in which one class was treated by using genre-based instructional (GBI) model and the second class was subjected to the process-based instruction (PBI) model. The writing test and creativity test were functioned as research instruments to collect the data in both classes. The data were analyzed by using the multifactor analysis of variance (ANOVA). The research finding informed that the GBI model was more effective than the PBI model. It was proved with the value of sig. (0.008) was lower than sig. level 0.05 . Thus, students having high creativity have better writing achievement than those who have low creativity and it was proved with the value of sign (0.000) was lower than sig. level 0.05. It means that the effect of instructional model and writing skills rests on the level of students' creativity. The finding indicates that there is significant interaction between instructional model being applied and creativity in the teaching of writing skills.
\end{abstract}

This is an open access article under the CC BY-SA license.

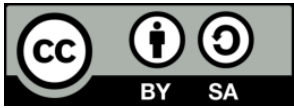

\section{Corresponding Author:}

Haerazi Haerazi,

Megister of English Education,

Mandalika University of Education,

Pemuda No. 59A Street, Mataram, West Nusa Tenggara, Indonesia.

Email: haerazi@ikipmataram.ac.id

\section{INTRODUCTION}

Writing activity is a form of manifestation of the most recent language skills that should be mastered by English preservice teachers after listening, speaking, and reading skills. Compared to three other skills, writing is more difficult to acquire than those even by English native speakers because writing skills require a mastery of various linguistic elements and aspects outside the language itself [1]. Preservice teachers need writing competences to be able to compose coherent and cohesion paragraphs. As stated in [2], the elements of language and content should be arranged well to meet the coherent and cohesion writing. Nevertheless, having a good writing skill for preservice teachers is difficult because they feel uneasy to compose an English essay [3].

Writing skills include one of language skills that involve active and productive abilities. Writing skills are an attempt to express thoughts and feelings that exist in a person by promoting language [4]. To achieve those efforts, preservice teachers should have an ability to use word diction, grammar, and writing mechanics including the use of capital letter, spelling, and punctuation [5]. In speaking skills, thoughts or ideas and feelings are conveyed verbally, while in the writing skills of thoughts and feelings are 
poured into the written form. The difference of the way this is delivered is characterized by different characteristics and different demands. These differences are certainly reflected in how the both skills are taught.

In ELT development, writing is a productive and expressive activity. Writers must be skilled at utilizing graphology, language structure, and vocabulary. To apply these rules into written form, the preservice teachers experienced difficulties. They still do awkward structure and unorganized paragraphs. It is in accordance with Mali [6], Aunurrahman [7], and Sitorus \& Sipayung [8] who reported that students still have low writing skills if they do not have enough knowledge of vocabulary, the organization of ideas, the grammar, and the mechanics. The mistakes made by the students in writing show that they still need to get serious attention, because these errors interfere with the success of the writing learning. Moreover, "learning writing is not an easy activity for many EFL learners who have insufiecient vulnerability outside of the class to authentic language" [9].

In Indonesian higher education, learning to write is a skill that needs long process to acquire. As stated in [10-12], language learners faced some factors as lack of writing experince, laguage deficiency, and low creativity and motivation. The fact that they can speak using the target language being learned, but they cannot write well and correctly happens in writing classes at higher education. They still have a limited creativity to negociate ideas into paragraphs. They also do mistakes in their writing composition. Some studies reported that some learning strategies and teaching models can be applied to encourage learners to be able to compose good paragraphs and mistakes can be reduced or even completely eliminated. Jaelani [13] proposes the content-based learning approach to facilitate learners to improve writing skills and creativity. Constructing corrective feedback also can help learners to correct grammatical errors they made $[14,15]$. A great deal of mistakes is regarded as indicators of some types of failure in teaching writing skills.

Teaching speaking is diferent from teaching writing although these two skills include the productive skill. In everyday language use, speaking is done in a higher number and frequency than writing. In the writing classes, many things happen and are experienced by preservice teachers in developing their writing skills. In expressing ideas and feelings, for example, there is certainly a mistake here and there, even though the opportunity to prepare and organize themselves is more than speaking skills. Writing looks very complex. For example, messages that need to be disclosed to be written into writing can be carefully chosen and arranged systematically, so that the writing can be understood correctly. Therefore, writing fluency is needed to be acquired. To help preservice teachers of having it, the genre-based instruction is appropriate to activate their background knolwedge [16]. In addition, the preservice teachers' writing mistakes can be solved through the steps of using genre-based instruction.

Other than linguistic aspects, creative thinking is fundamental for preservice teachers. It can give a negative effect for writing skills because creative skill is an essential factor affecting the coherent and cohesion writing composition. This skill includes an essential $21^{\text {st }}$ century learning skill $[17,18]$. The role of creativity in fostering preservice teachers' writing skills is considered as the process to construct ideas in the form of paragraphs or texts [19]. Preservice teachers are trained to think creatively. Having high creative thinking helps them to arrange and create new ideas in their learning [20]. Therefore, creativity is very crutial factor to generate a good writing.

To attain the writing skills and creativity, this study proposed the genre-based instructional model. As stated in [21], the genre-based instruction is referred to teach writing classes on how learners apply language patterns in texts in order to become a coherent, cohesion, and purposeful composition. It also is highlighted by the theory of systemic functional grammar. This view addresses the relationship between language and its function related to social life and sets out to see how language is as a system from which language users create choices to express meanings [22, 23]. Moreover, the genre-based instructional model can be employed to teach speaking, listening, and reading skills because this model doesn't pay attention only to writing skills but all language skills [24]. It is reinforced by Paltridge [25] who states the genre has been applied in many fields including applied linguistics. In this study, the genre is considered as text types because any text is related to a genre.

Genre is an option to facilitate language learners to communicate in writing [26]. Genre-based instruction model has proven to be an effective pedagogy through attention to discoursal features, which are preservice teachers' awareness of textual and rhetorical features through learning tasks [27]. Therefore, using the genre-based instructional model is a promising practice. Lectures are required to involve students to write or produce a text on the basis of the writing purpose, organization, and reader. In addition, Negretti and McGrath [28] depicts that "this model focuses heavily on the reader and on the conventions that a piece of writing entails to fulfill in order to be an acceptable writing text for readers". For these reasons, this model is believed to provide some benefits to stimulate students to be creative learners to write. It also is assumed to be able to enhance students' writing skills at higher education. 
To see the effectiveness of the genre-based instructional model, this study was also focused on students' creativity to write. This psychological aspect is assumed that it influences the success of writing learning. In the writing class, students think more about the ideas than write those into the paper. Furthermore, the idea itself derives from creativities. Creativity itself refers to the students' ability to create and develop new idea seen from fluency, flexibility, and authentic thinking based on their prior knowledge towards a new situation [29].

Finally, this study proposed some research questions; (1) is the use of Genre-based instructional (GBI) model more effective than the existing conventional model to teach writing skills for fourth semester students of English language education study program? (2) Do the students having high creativity have better writing skills than those having low creativity? And (3) is there any interaction between instructional model and creativity to teach writing skills for the fourth-semester students of English language education study program? The novelty of this study lies in the use of genre-based instructional model to improve preservice teachers' writing skills viewed from the level of their creativity. The creativity here is a thinking process to construct ideas seen from fluency, flexibility, and authentic thinking.

\section{LITERATURE REVIEW}

\subsection{Teaching writing skills in higher education}

Teaching writing skills in higher education emphasize the processes how students practice to write. It is by some lecturers called the process-based instruction. This instruction is considered by language researchers as activities that restrict students to explore their ideas to produce a text. This model does not see the end of writing activities to produce a complete text type. To underpin this instruction, lecturers in higher education echo the product-based instruction. Coffin et al. [30] state "when writing skills have been explicitly subjected to higher education, the emphasis has been on writing text as a final product".

The process and product-based instruction in the teaching of writing has been increasingly applied. According to Harmer [31], the writing process is admitted as stages for students to go through in order to come to its final written form. In the class, students are provided a certain topic to write. The process then is designed in stages. The stages applied mostly by lecturers who intend to this include four stages, namely planning, drafting, editing, and publishing. In the same tune, Syarof et al. [32] adopt the stages of writing process cover pre-writing, drafting, sharing and responding, revising and editing, and publishing. It is reinforced by Rosinovci [33] who argues the publishing phase is the last stage for students to present their complete writing text as a result of taking a long process of learning.

The process-based instruction has different aims of learning rather than the product-based instruction. The product-based instruction is believed by lecturers at higher education enable to improve students' writing skills. In class, students are asked to read a book or article first and then they write what they understand from it. That is the same tune with Haerazi [34] who describes the product-based instruction nowadays is acknowledged by text-based instruction. Thus, text-based instruction becomes one of communicative frameworks echoed by Richards [35]. The other name of it is called by the genre-based instructional (GBI) model.

\subsection{Genre-based instructional model}

The genre-based instruction is one of the outstanding English language teaching (ELT) models recently including in curriculum 2013 (C.2013) in Indonesia. This model approaches language learning process from texts. It requires an instructional methodology that enables students' knowledge and skills to deal with written texts in line with social contexts [36]. The genre-based instruction is also a kind of approach that sees communicative competencies involving the mastery of various types of texts [35]. In short, it is a language learning model focusing on what students do with language through texts and the objectives of this model are related to the use of texts in its context.

Hommond et al. [37] and Emilia [38] provide five stages of GBI model. These include building knowledge of the field; modeling of the text; joint construction of the text; independent construction of the text; and linking related text. In applying the direct instruction, the teacher also provides questioning in the teaching-learning process, which goes through the following steps adapted by Burgos [39] and Dirgeyasa [40] as follows:

\subsubsection{Building knowledge of the field}

This stage aims to build students' knowledge about topics that will be written. Building knowledge of the field differs from building knowledge of the text. Building knowledge of the field refers to a depiction of topics going to write. Meanwhile, building knowledge of the text refers to an explanation of generic 
structure and linguistic features of the text. To help students about topics, lectures give any text relating to the topic that will be written. Students are then asked to read a first text and given some questions of the text.

\subsubsection{Modeling of the text}

This stage involves introducing students to a model of the genre they are going to write. The text provided is called as a text model. It will be different from the task done in the first stage, which aims to build students' knowledge of the whole context of the topic [37]. In addition, the activities of this stage involves (a) familiarizing students with the function and social context of the genre, (b) presenting the schematic structure of the genre, (c) presenting a model text of the genre, and (d) presenting other texts in the discussion genre [38].

\subsubsection{Joint construction of the text}

This stage aims to construct a similar text as the continuation of the initial second stage. This stage requires for lecturers to work with students to make the model text as a construction process. The emphasis of this stage is that "lecturers or teachers provide guidance and support in order to convert and reshape language from the spoken to the written mode" [37]. In addition, three activities in doing joint construction of the text include (a) grouping students into 2-3 students of each group and familiarizing them with the task going to do, (b) approaching each group at the start of the joint construction, and (c) conducting discussion session with each group about their drafts [24, 39].

\subsubsection{Independent construction of the text}

Teacher should assess the students whether they are ready to construct the text independently. According to students' need, it may be necessary to reshape some tasks and activities in earlier stages. Besides, lecturers need to suggest "students' capacity to relate the text with their reality and to make sense of the world around them" [38]. After knowing students' capacity, when students have enough knowledge about the topics and text model, lecturers ask them to move to write independently.

\subsubsection{Linking related text}

This stage involves students to investigate how they have learnt in each stage can be related to other texts in the same or similar context. Feez and Joyce [36] argue in linking related texts students do activities such as (a) comparing the use of text-type across different context and topics but in the same genre, (b) researching other text type being to write in the same context, (c) role-plying what happens if the same text type is used in different roles and relationships, (d) comparing spoken and written text model, and (e) analyzing how linguistic features used in the text model is employed in other text models.

\subsection{Creativity of writing}

Creativity is intellectual abilities, knowledge, and thinking styles [41]. It means creativity students' capacity, refers huge information, and they are able to elaborate ideas reflecting language styles. This claim is supported by Hennessey [42] who states "creativity is not a trait that students inherit in their genes or a blessing bestowed by the angels". Creativity is a skill that learners can achieve and learn it. Therefore, creative language learners are creative people largely not by inborn trait, but beyond an attitude toward life.

Creativity and intelligence are restively related [43]. Creativity activities always involve a thinking process. Lecturers who do not understand the learners' creativity would have troubles to facilitate the learning process of developing the learners' potential. The learners' potentials and abilities would be developed well if the learning process is directed to achieve that aim. If so, learners are able to create and develop their ideas in the class. It is in line with Gajda, et al. [44] who states a thinking process, to create ideas, approaches, and products, is a piece of creativity.

\section{RESEARCH METHOD}

\subsection{Research setting}

This study was conducted at Faculty of Language and Art Education, Mandalika University of Education Mataram. This study is a continuation of the dissertation study involving the writing lecturers at Mandalika University of Education. The data was collected in November 2018-February 2019. Based on the initial interview with the English lecturers, the use of genre-based instructional model in teaching writing competences had never been employed before for fourth semester students. The writing lecturers only asked students to write and complete some tasks without any alternative teaching-learning model. The existing learning process was then called as the control group and the genre-based instructional learning was addressed as the experimental group. This study was administered in line with the subject of the writing 
schedule. The treatments were given in both groups in five meetings. The last meeting was associated with the posttest part.

\subsection{Research design}

This study was quasi-experimental research design. The independent variable in this study was the genre-based instructional model and the existing instructional model, whereas the dependent variable was the writing skill. Meanwhile, the creativity was an attribute variable assumed as the independent variable because it influenced the dependent variable (writing skills). This study used a factorial design. The two independent variables were the factors that were manipulated, measured, and selected to find out the effect and correlation to the facts being investigated. The two variables were associated with two groups of students. The genre-based instructional (GBI) model was functioned as the experimental group and the existing instructional model was utilized as the control group.

The creativity was as the secondary independent variable or the attribute variable that affected the dependent variable (writing skills). This study investigated the effectiveness of the instructional model (X) towards writing skills (Y). Then, the interaction between X and Y was affected by the students' creativity (Z). In addition, both groups were given a posttest. The results were analyzed by comparing the posttest of the two groups. The Two Way Analysis of Variance (ANOVA) was applied in this study. The design of Two Way ANOVA can be seen in Table 1.

Table 1. Design of two-way ANOVA

\begin{tabular}{lll}
\hline \multicolumn{1}{c}{ Creativity Level } & \multicolumn{2}{c}{ Instructional Model } \\
& Genre-Based Instruction & Process-Based Instruction \\
\hline High Level (B1) & A1B1 & A2B1 \\
Low Level (B2) & A1B2 & A2B2 \\
Mean & A1 & A2 \\
\hline
\end{tabular}

\subsection{Participants}

In this study, the population was the fourth semester students of English language education study program of FPBS, Mandalika University of Education Mataram. The fourth semester of that was divided into three classes which are IVA, IVB class, and IVC. Each class included 96 students. The total population was 64 students. The sample of this study covered the IVA and IVB class. The sample was taken randomly using cluster random sampling technique. Therefore, the IVA class was functioned as the experimental class taught by using GBI model and IVB class was functioned as the control class taught by implementing PBI model.

In deciding the experimental class and control class, the researcher made two sessions of lotteries and took randomly. The first session of the lottery was the experimental class (IVA class) and the second session was the control class (IVB). The symbol of the experimental class was A1 and control class was A2. Meanwhile, the symbol of high creativity was B1 and low creativity was B2. In dividing the two classes into the group students having high and low creativity, the researcher took 50\% students (16 students) having high creativity and 16 students having low creativity from both the experimental and control class.

\subsection{Data collection technique}

To collect the research data, the researcher created a writing test and creativity test for both experimental and control class. For the writing test, students were asked to create a narrative text. The form of the writing test involved an essay test. The instruments was administered by considering the standard of writing instructional goals and learning objectives for fourth semester students at English language education study program. Afterwards, the researcher employed a scoring rubric to assess writing skills. The aspects of writing skills that are assessed consisted of content, organization, vocabulary, grammar, and mechanics $[1,45]$. These aspects were reflected in the writing assessment.

The creativity test was aimed at investigating the students' level of creativity. The form of the creativity test in this study was verbal creativity test. It was chosen because it associated with relationship of words, vocabularies, and communication. Then, the verbal creativity was valued by using creativityscoring rubric. The readability of writing and creativity instrument was considered. There were several questions in line with the instruction of the creativity and writing test. It was said as a readability test because $75 \%$ of students gave answer 'Yes' in the questionnaire. Besides, the content validity and the reliability of instruments were measured.

\subsection{Data analysis technique}

This study applied a descriptive and inferential analysis. The descriptive analysis was applied to know students' mean, median, mode, and standard deviation of scores. The inferential was used to test 
the research hypothesis of the study. The result of testing hypothesis was functioned to manage the research data in the form of numbers and it can produce a research conclusion. Furthermore, the data was viewed from the normality and homogeneity. The normality test was conducted to know whether the data have a normal distribution or not. One Sample Komogorov-Smirnov formula was employed. The analysis showed the data were normal because the value of sig. was higher than sig. level 0.05 . Meanwhile, the homogeneity test was conducted to know whether sample chosen has the same variance. Levene test was applied. The result indicated the data variance was homogeneous because the value of sig. was higher than sig. level 0.05.

The inferential analysis in this study used a parametric statistical technique, which was multifactor analysis of variance (Two Way ANOVA). The null hypothesis (Ho) was rejected because Fo was higher than Ft. Besides, to find the significant difference from one to another, Tukey test was applied. It was a statistical test used in accordance with ANOVA computation. The computation of the inferential analysis utilized the statistical device of IBM SPSS 21.0.

\section{RESULTS AND DISCUSSION}

\subsection{Research findings}

The descriptive analysis presented the score of posttest from the experimental and control group. The writing test was done by giving students an essay test of a narrative text for both groups. Table 2 presents the students' writing skills for both the experimental and control group.

Table 2. The result of students' writing skills

\begin{tabular}{|c|c|c|c|}
\hline \multicolumn{2}{|c|}{ Descriptive Statistic } & \multirow[t]{2}{*}{ Experimental Group } & Control Group \\
\hline & Valid & & 34 \\
\hline$N$ & Missing & 0 & 0 \\
\hline Mean & & 80.76 & 77.68 \\
\hline Media & & 80.00 & 79.00 \\
\hline Mode & & $78^{\mathrm{a}}$ & 80 \\
\hline Std. D & & 8.057 & 5.623 \\
\hline Minin & & 68 & 64 \\
\hline Maxir & & 96 & 87 \\
\hline Sum & & 2746 & 2641 \\
\hline
\end{tabular}

The students' writing skills at the two groups showed that the students had different achievement for writing skills. It can be influenced by students' level of creativities. The level of creativities was significant effect in developing students' writing skills. In this study, the researchers divided the level of students' creativities into two categories, namely students having high creativity and low creativity. The results can be seen in Table 3 and Table 4.

Table 3. The result of writing skills of students having high creativity

\begin{tabular}{|c|c|c|c|}
\hline \multicolumn{2}{|c|}{ Descriptive Statistic } & $\begin{array}{l}\text { High Creativity in } \\
\text { Experimental Group }\end{array}$ & $\begin{array}{l}\text { High Creativity in Control } \\
\text { Group }\end{array}$ \\
\hline \multirow{2}{*}{$\mathrm{N}$} & Valid & 17 & 17 \\
\hline & Missing & 17 & 17 \\
\hline Mean & & 86.94 & 81.59 \\
\hline Media & & 85.00 & 80.00 \\
\hline Mode & & $80^{\mathrm{a}}$ & 80 \\
\hline Std. D & ion & 5.425 & 2.959 \\
\hline Minim & & 80 & 78 \\
\hline Maxin & & 96 & 87 \\
\hline Sum & & 1478 & 1387 \\
\hline
\end{tabular}

Table 4. The result of writing skills of students having low creativity

\begin{tabular}{|c|c|c|c|}
\hline \multicolumn{2}{|c|}{ Descriptive Statistic } & $\begin{array}{c}\text { Low Creativity in } \\
\text { Experimental Group }\end{array}$ & $\begin{array}{c}\text { Low Creativity in Control } \\
\text { Group }\end{array}$ \\
\hline \multirow[b]{2}{*}{$\mathrm{N}$} & Valid & בת & 17 \\
\hline & Missing & 17 & 17 \\
\hline & 74.59 & 73.76 \\
\hline \multicolumn{2}{|c|}{ Median } & 76.00 & 74.00 \\
\hline \multicolumn{2}{|c|}{ Mode } & 78 & $70^{\mathrm{a}}$ \\
\hline \multicolumn{2}{|c|}{ Std. Deviation } & 4.836 & 4.893 \\
\hline \multicolumn{2}{|c|}{ Minimum } & 68 & 64 \\
\hline \multicolumn{2}{|c|}{ Maximum } & 82 & 80 \\
\hline \multicolumn{2}{|c|}{ Sum } & 1268 & 1254 \\
\hline
\end{tabular}


Before conducting inferential statistical analysis, the data should meet the normality and homogeneity. The data were decided as normal data because the value of sig. was higher than sig. level 0.05. Then, the data were concluded as homogeneous data because the value of sig. was greater than sig. level 0.05 . The summary of normality test and homogeneity test can be seen in Table 5 and Table 6 .

Table 5. Summary of normality test

\begin{tabular}{lccc}
\hline Groups & \multicolumn{3}{c}{ Kolmogorov_Smirnov Z } \\
\hline Instructional Model & Std. Deviation & Df & Asymp. Sig. (2-tailed) \\
GBI Model (A1) & 8.057 & 34 & .878 \\
PBI Model (A2) & 5.623 & 34 & .134 \\
\hline
\end{tabular}

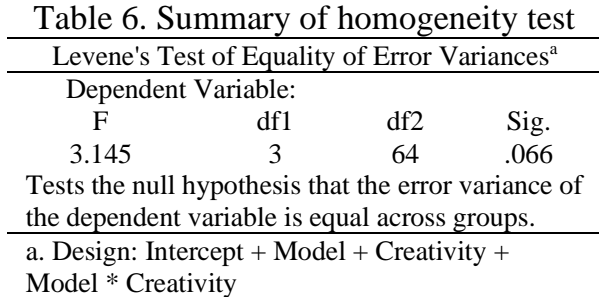

After the data meet the normality and homogeneity, the computation of inferential statistic was carried out. The interaction of between the instructional model being applied and the students' creativity level can be seen at Table 7. Besides, the result of instructional model for both groups was presented at Table 8 and the result of students' creativity mean score each group was computed as seen at Table 9. In addition, Table 10 explains the result of interaction between the instructional model applied and the creativity. The two groups were seen from the level of students' creativity and the two learning models.

Table 7. Summary of ANOVA test

\begin{tabular}{lcrrrr}
\hline \multicolumn{2}{c}{ Tests of Between-Subjects Effects } & & \\
\multicolumn{1}{c}{$\begin{array}{c}\text { Dependent Variable: Writing Skill } \\
\text { Type III Sum of } \\
\text { Squares }\end{array}$} & df & Mean Square & F & Sig. \\
\hline Corrected Model & $1979.456^{\text {a }}$ & 3 & 659.819 & 30.863 & .000 \\
Intercept & 426761.309 & 1 & 426761.309 & 19962.008 & .000 \\
Model & 162.132 & 1 & 162.132 & 7.584 & .008 \\
Creativity & 1730.132 & 1 & 1730.132 & 80.928 & .000 \\
Model * Creativity & 87.191 & 1 & 87.191 & 4.078 & .048 \\
Error & 1368.235 & 64 & 21.379 & & \\
Total & 430109.000 & 68 & & & \\
Corrected Total & 3347.691 & 67 & & &
\end{tabular}

a. $\mathrm{R}$ Squared $=.591$ (Adjusted R Squared $=.572$ )

Table 8 . The result of instructional model mean score

\begin{tabular}{ccrrr}
\hline \multicolumn{5}{c}{ 1. Instructional Model } \\
\hline & \multicolumn{4}{c}{ Dependent Variable: Writing Skill } \\
Model & Mean & Std. Error & 95\% Confidence Interval \\
& & .793 & 79.181 & 82.349 \\
GBI Model & 80.765 & .793 & 76.092 & 79.261 \\
PBI Model & 77.676 & &
\end{tabular}

Table 9. The result of students' creativity mean score

\begin{tabular}{lcrrr}
\hline \multicolumn{5}{c}{ 2. Creativity } \\
\hline Creativity & Mean & Std. Error & 95\% Confidence Interval \\
High & 84.265 & .793 & 82.681 & Lower Boun \\
Low & 74.176 & .793 & 72.592 & 85.849 \\
\hline
\end{tabular}


Table 10. The result of instructional model \& creativity mean score

\begin{tabular}{ccrrrr}
\hline \multicolumn{5}{c}{ 3. Model * Creativity } \\
\hline \multirow{2}{*}{ Model } & & Mean & Std. Error & 95\% Confidence Interval \\
GBI Model & High & 86.941 & 1.121 & 84.701 & Lower Bound \\
& Low & 74.588 & 1.121 & 72.348 & 76.829 \\
PBI Model & High & 81.588 & 1.121 & 79.348 & 83.829 \\
& Low & 73.765 & 1.121 & 71.524 & 76.005 \\
\hline
\end{tabular}

The genre-based instructional model in teaching writing skills directed preservice teachers to practice much more to write in the class. It made them easy to organize their writing and at the same time produce a complete narrative text. Statistically, Table 2 presents that the mean score of students taught by using the genre-based instructional model was 80.76 and of those taught by applying the conventional one was 77.68. It means that the GBI model was effective in the teaching of writing skills for the fourth semester students of English language educational study program.

In addition, the source of model column in Table 7 shows that the value of sig. (0.008) was lower than sig. level 0.005 . It indicated the GBI model was significantly different from the one using conventional model. The finding of this study informed that the GBI model is more effective instructional model than the conventional model to teach writing skill because the mean score of students who are taught by applying the GBI model is higher than that of those taught by using the conventional model.

The GBI model seems potential to develop students' knowledge of the text before they start writing. For instance, in the first step of building knowledge of the field preservice teachers are led to the knowledge of when and where to sue the text, for whom, why, and for what purposes. It enables for students to complete a meaningful and readable text. It is in line with Nurlaelawati and Novianti [46] who reported in their research finding that the step of building knowledge of the field is the most important stage in applying pedagogy of GBI model because this stage leads preservice teachers' knowledge of when and where to create the text, for whom, why, and for what aims, so that the text becomes meaningful for them. In addition, Hyland [47] reinforce that during the building knowledge process preservice teachers are introduced with cultural and linguistic resources necessary for them to engage critically with texts.

The GBI model helps preservice teachers to understand the topics that they are going to write. Before practice writing, they do reading activities in the class and discuss the text. They identify some words and expressions that they do not understand from the text. They sometime guess word and expression meaning and ask to the lecture the exact meaning. In doing so, students acquire vocabularies, grammars, and expressions from the text. Therefore, by applying the GBI model, students can explore and build their linguistic and discourse competencies. As the result of learning, preservice teachers are able to improve their linguistic competencies in the step of building knowledge of the field [48]. This finding is little bit different from Abbaszadeh [49] who argues that learners can build cultural context, share experience, discuss vocabulary, and grammatical pattern since the learners are geared around text types and topics they are going to deal with at the second stage of GBI model.

In making an introduction paragraph of narrative texts, the research finding informed that students are introduced first with providing a complete narrative text as a model text. They analyze the language features, who in the story, when the story taking place, and where the story happening. It leads students to write complete paragraph of narrative texts. In the second step of the GBI model (the step of text modeling), students are given opportunity for students to familiarize the language features of narrative texts. At the end of these activities, students are able to present their own introduction paragraph of narrative texts. It is in accordance with Emilia [38] who states that showing other texts in the discussion genre is the aim of modeling of the text.

The implementation of the GBI model is exactly appropriate with developing the $21^{\text {st }}$ students' skill globally and 2013 curriculum in Indonesia. In the $21^{\text {st }}$ century learning, Madya [50] argues peoples cannot be inseparable from global communication. The global communication can happen if students have communicative competencies. Moreover, Richards [51] state the GBI model is a kind of language instruction that sees communicative competences can be mastered with providing language activities through and with different types of texts. The research finding informed that the steps of GBI model asked students to read and identify various texts and discuss it in a small group.

Students felt easy to arrange the narrative text when they followed the entire steps of the GBI model. For an example, in the step of the independent construction of the text, the students' awareness of the effect of grammar, mood of sentences, the use of modality and pronouns can be solved in this step. In learning activities of this stage, students are encouraged to write a narrative text relating to their reality and the world around them. Students are divided into 2-3 students of each group. Afterwards, when students have enough

Triggering preservice teachers' writing skills through genre-based instructional... (Haerazi Haerazi) 
background knowledge of the topic and are ready to write independently based on their agreement. It is in line with Feez \& Joyce [36] who state this stage encourages students to work independently with the text.

Teaching writing class by implementing the process-based instruction also interesting, but it cannot meet activities as the genre-based instruction does. The PBI model focused only on stages of writing activities such as pre-writing, drafting, revising, editing, and publishing. PBI model restricts students to elaborate their ideas in certain topics being to write. It is reinforced by Qomariyah and Permana [52] who state that the PBI model can help preservice teachers arrange a simple paragraph, but students are still difficulties in composing sentences into complete texts of descriptive texts or narrative texts. Based on the research finding in the control group, the preservice teachers' creativity doesn't give a significant effect to improve students' achievement in writing class. Those having high creativity or intelligence feel uneasy to enhance their writing ability by using the PBI model.

Dealing with the preservice teachers' creativity in the experimental group, the GBI model helps learners to enhance their writing achievement. Based on the data analysis in Table 7, the source of creativity column indicated that the value of sig. (0.000) was lower than sig. level 0.05. It means that students who have high creativity are significantly different from those who have low creativity. According to Table 9 , the mean score of writing skill of students having high creativity (84.265) was higher than that of those having low creativity (74.176) from both groups, the experimental and control group. It means that students having high creativity have better writing achievement that those having low creativity.

The research finding informed that students who have high creativity tend to be autonomous, have good interest, and have good attitude to learn. Students having high creativity incline to take the challenging writing activities provided by lecturers to complete their writing assignments. They have good selfconfidence to accomplish any writing tasks given by lecturers. As an outcome of this, students having high creativity have a realistic writing achievement. They have strong emotions, optimistic, more risk-taking, and independent learners. It is in line with Rahmatika [53] who found in her research that learners having high creativity have a broad creation and thinking to create paragraphs in the writing class. In addition, Soffiani [54] states "students who have high creativity tend to be independent, high interest, and opened minded to face new experience".

Dealing with the correlation between instructional model and students' creativity, the statistical analysis in the source of instructional model*creativity column informed that the value of sig. (0.048) was lower than sig. level 0.05 . It proved that there is significant correlation between the instructional models and students' creativity in teaching of writing skills for fourth semester students of English language education.

The research finding informed that the choice of an appropriate instructional model influenced the preservice teachers' achievement in the teaching of writing skills in particular. Lecturers should employ the suitable instructional model to involve preservice teachers in more active learning activities. This study showed that the GBI model gives positive effect and raises interesting learning activities. As the result, preservice teachers' writing skills improve. It is line with Coffin et al. [30] and Emilia [24] who found the GBI model brings preservice teachers to construct their ideas, amend the awareness of grammars, vocabularies, and contents. Therefore, the learners having high creativity felt easy to arrange their writing into paper. Moreover, the research finding is in accordance with Haerazi, at al. [55] that depict preservice teachers are able to play a role as autonomous learners in constructing a complete descriptive text through the implementation of the genre-based instruction.

\section{CONCLUSION}

The teaching steps of the genre-based instructional (GBI) model include five stages; (1) building knowledge of the field, (2) modeling of the text, (3) joint construction of the text, (4) independent construction of the text, and (5) linking related text. Each stage has the purpose to be achieved. The result of this study can be concluded that (1) the GBI model is more effective than the PBI model in the teaching of writing skills, (2) students who have high creativity have better writing skills than those who have low creativity at the fourth semester students of English language education study program, and (3) there is significant correlation between instructional model being applied and creativity in the teaching of writing skills at the fourth semester students of English language education study program of Mandalika University of Education.

\section{ACKNOWLEDGEMENTS}

Parts of this paper have been presented at the $4^{\text {th }}$ Asia Pacific Education Conference (AECON 2017). This study was funded by Mandalika University of Education (Undikma) Mataram in the form of the sustainable human resource development program for ELT lecturers of FPMB Undikma Mataram and 
RISTEKDIKTI for Thesis Writing Fund. Also, authors thank to all colleagues who have constributed in any part of this manuscript.

\section{REFERENCES}

[1] H. Haerazi, \& L. A. Irawan, "Practicing genre-based language teaching model to improve students' achievement of writing skills,". IJELTAL (Indonesian Journal of English Language Teaching and Applied Linguistics), vol. 4, no. 1, pp. 9-18. 2019.

[2] Haerazi, Language Teaching Approach (in Bahasa), Yogykarta: Samudera Biru Press, 2010.

[3] U. F. Miatin \& P. Wiedarti, "Empowering students' personal recount writing and motivation to write through selfregulated strategy development model," Journal of Education and Learning (EduLearn), vol. 13 , no. 2 , pp. 177-183, 2019.

[4] M. F. F. Abbas, \& H. Herdi, "Solving the students' problems in writingargumentative essay through collaborative writing strategy. English Review:Journal of English Education, vol. 7, no. 1, pp. 105-114, 2018.

[5] F. S. Utami, M. Pabbajah, \& J. Juhansar, "The implementation of jumbled sentences toward students' skill in writing report text," English Review: Journal of English Education, vol. 7, no. 1, 115-124, 2018.

[6] Y. C. G. Mali,"Motivational teaching strategies in Indonesian EFL writing classrooms," Celt: A Journal of Culture, English Language Teaching \& Literature, vol. 17, no. 1, pp. 60, 2018.

[7] Aunurrahman, A., Hamied, F. A., \& Emilia, E., "A joint construction practice in an academic writing course in an indonesian university context," Celt: A Journal of Culture, English Language Teaching \& Literature, vol. 17, no. 1, pp. 27, 2018.

[8] G. S. Sitorus., \& K. Sipayung, "An error analysis of using phrases in writing recount text at tenth grade in SMA Parulian 2 Medan," Celt: A Journal of Culture, English Language Teaching \& Literature, vol. 18, no. 1, pp. 74, 2018.

[9] A. Yundayani, S. Susilawati, \& C. Chairunnisa," Investigating the effect of Canva onstudents' writing skills," English Review: Journal of English Education, vol. 7, no. 2, pp. 169-176, 2019.

[10] Z. Ying, "Exploring construction of college English writing course from the perspective of output-driven hypothesis," English Language Teaching, vol. 11, no. 2, pp 188, 2018.

[11] A. Yundayani, "Present situation analysis: Students' early characteristics in writing for academic purposes," English Review: Journal of English Education, vol. 6, no. 2, pp. 119-126, 2018.

[12] Y. Zhang, "Exploring EFL learners' self-efficacy in academic writing based on processgenre approach," English Language Teaching, vol. 11, no. 6, pp. 115, 2018.

[13] S. R. Jaelani, "Treating of content-based instruction to teach writing viewed from EFL learners' creativity," English Language Teaching, vol. 10, no. 11, pp. 156-161, 2017.

[14] K. Sermsook, J. Liamnimitr, \& R. Pochakorn, "The impact of teacher corrective feedback on EFL student writers' grammatical improvement," English Language Teaching, vol. 10, no. 10, pp. 43, 2017.

[15] P. G-L. Chew, "Language use and discoursal strategies in peer religious mentoring," Journal of English Language Teaching and Linguistics, vol. 1, no. 3, 2016.

[16] D. Miller, "Promoting genre awareness in the EFL classroom," English Teaching Forum, vol. 2, no. 1, pp 2-15, 2011.

[17] L. Donovan, T. D. Green, \& C. Mason, "Examining the 21st century classroom: Developing an innovation configuration map," Journal of Educational Computing Research, vol. 50, pp. 161-178, 2014.

[18] A. J. Rotherham., \& D. T. Willingham, "The 21st-Century skills: Not new, but a worthy challenge," American Educator, Spring, pp. 17-20, 2010.

[19] A. Rahmatika, "The effectiveness of student teams achievement division to teach writing viewed from students' creativity," International Journal of Language Education, vol. 3, no. 1, pp.46-54, 2019.

[20] L. Khikmah, "Teachers' creativity in designing learning activities: Sustaining students' motivation," English Review: Journal of English education, vol. 7, no. 2, pp. 85-92, 2019.

[21] Hyland, K., "Genre pedagogy: Language, literacy and L2 writing instruction," Journal of Second Language Writing, vol. 16, no. 3, pp. 148-164, 2007.

[22] Hyland, K. "Genre-based pedagogies : A social response to process," Journal of Second Language Writing, vol. 12, pp. 17-29, 2003.

[23] Haerazi, "Genre-based language learning model in teaching writing skills for english department students," 109 (Aecon), pp. 108-111, 2017.

[24] E. Emilia, Genre-based approach in teaching English: Guidance for teachers(in Bahasa). Bandung: Rizki Press, 2011.

[25] Paltridge, B. Genre and the language learning classroom, Ann Arbor, MI: University of Michigan Press, 2001.

[26] C. M. Tardy, Beyond convention: Genre innovation in academic writing. Ann Arbor, MI: University of Michigan Press, 2016.

[27] A. Cheng, "Language features as the pathways to genre: Students' attention to non-prototypical features and its implications," Journal of Second Language Writing, vol. 20, no. 1, pp. 69-82, 2011.

[28] R. Negretti., \& L. McGrath, "Scaffolding genre knowledge and metacognition: Insights from an L2 doctoral research writing course," Journal of Second Language Writing, vol. 40, pp. 12-31, 2018.

[29] E. Kupers, A. Lehmann-Wermser, G. McPherson, \& P. van Geert, "Children's creativity: A theoretical framework and systematic review," Review of Educational Research, vol. 89, no. 1, pp. 93-124, 2019. 
[30] C. Coffin, M. J. Curry, S. Goodman, A. Hewing, T. M. Lilis, \& J. Swann, Teaching academic writing: A toolkit for higher education. New York: Routledge, 2003.

[31] J. Harmer, How to teach writing. London: Pearson Education, 2004.

[32] A. Syarof, D. Kuswahono., \& H. Rizky, "Implementing process writing strategy using weblogs to improve students' ability in writing descriptive text," Lingua Cultura, vol. 12, no. 4, pp. 351-355, 2018.

[33] X. Rusinovci, "Teaching Writing Through Process-Genre Based Approach,", vol. 5, no. 10, pp. 699-705, 2015.

[34] Haerazi, Developing an interculture-based language learning model in the teaching of writing skills for English language education in higher education. S3 Dissertation, Dept. of Language Education Science, UNY, 2018.

[35] J. C. Richards, "Communicative language teaching today. New York: Cambridge University Press, 2006.

[36] Feez, S., \& Joyce, H, "Text-based syllabus design. Sydney: National Cntre for English Language Teaching and Research, 2002.

[37] J. Hammond, A. Burns, H. Joyce, D. Brosnan, L. Gerot, N. Solomon, \& S. Hood, English for social purposes: A handbook for teachers of adult literacy. Sydney: National Centre for English Language Teaching and Research, Macquarie University, 1992.

[38] E. Emilia, A critical genre-based approach to teaching academic writing in a tertiary EFL context in Indonesia, PhD thesis, Dept. of Language, Literacy, and Arts Education, University of Melbourne, 2005.

[39] Burgos, E. G. "Use of the genre-based approach to teach expository essays to English pedagogy students," $\mathrm{HOW}$, vol. 24, no. 2, pp. 141-159, 2017.

[40] I. W. Dirgeyasa, "Genre-based approach: what and how to teach and to learn writing," English Language Teaching, vol. 9, no. 9, pp. 45, 2016.

[41] T. I. Lubart, \& R. J. Sternberg, "An investment approach to creativity. In S. M. Smith, T. B. \& Finke (Eds.)," The creative cognition approach, pp. 269-302, Cambridge, MA: MIT Press, 1995.

[42] B. A. Hennessey., \& T. M. Amabile, "Creativity," Annual Review of Psychology, vol. 61, pp. 569-598, 2010.

[43] V. P. Glăveanu, "Principles for a cultural psychology of creativity, Culture \& Psychology, vol. 16, pp. 147-163, 2010.

[44] A. Gajda, R. A. Beghetto, \& M. Karwowski, "Exploring creative learning in the classroom: A multi-method approach," Thinking Skills and Creativity, vol. 24, pp. 250-267, 2017.

[45] Brown, H. D., Teaching by principles; An interactive approach to language pedagogy. $2^{\text {nd }}$ Edition. San Francisco: Pearson Longman, 2004.

[46] Nurlaelawati, I., \& Novianti, N., "The practice of genre-based pedagogy in Indonesian schools: a case of preservice teachers in Bandung, West Java Province," Indonesian Journal of Applied Linguistics, vol. 7, no. 1, pp. 160, 2017.

[47] K. Hyland, "Genre-based pedagogies: A social response to process," Journal of Second Language Writing, vol. 12, pp. 17-29, 2003.

[48] L. T. Tuan, "Teaching writing through genre-based approach," Theory and Practice in Language Studies, vol. 1, no. 11, pp. 1471-1478, 2011.

[49] Z. Abbaszadeh, "Genre-based approach and second language syllabus design," Procedia-Social and Behavioral Sciences, vol. 84, pp. 1879-1884, 2013.

[50] Madya, S. Metodologi pengajaran bahasa; dari era premetode sampai pasca metode. Yogyakarta: UNY Press, 2013.

[51] J. C. Richards, Communicative language teaching today. New York: Cambridge University Press, 2006.

[52] Qomariyah, S. S., \& Permana, D. "Process based approach towards students' creativity in writing English paragraph," Www.ijeltal.org Indonesian Journal of English Language Teaching and Applied Linguistics Qomariyah \& Permana, vol. 1, no. 11, pp. 37-47, 2016.

[53] Rahmatika, A. "The effectiveness of student teams achievement division to teach writing viewed from students' creativity," International Journal of Language Education, vol. 3, no. 1, pp. 56-54, 2019.

[54] Soffiany, N. K. The effectiveness of project-based learning to teach writing in relation to students' creativity. S2 Thesis, English Education Department, Yogyakarta State University, 2017.

[55] Haerazi, H., Irwansyah, D., Juanda, J., \& Azis, Y. A. "Incorporating intercultural competences in developing English materials for writing classes," Journal of Language Teaching and Research, vol. 9, no. 3, pp. 540-547, 2018. 